\title{
The Role of a Voluntary Agency in Tuberculosis Control
}

\author{
by \\ Lee, Chan-Sae, M. D. \\ President of the Korean National Tuberculosis Association \\ Presented atthe IXth Tuberculosis (Conference of Eastern Region) \\ of the International Union Against Tuberculosis \\ New Delhi, India November, 1974
}

민간단체의 역활을 요약하면,

첫째는 선도자와 교육자로서의 역활을 들 수 있다.

한 국가에 있어 결핵사업은 전적으로 정부의 책임에 속하지 만, 정부가 걸핵사업에 소요되는 예산 을 확보하고, 또 모든 국민이 결핵사업의 중요성을 인식할 수 있게 하는 일이 그리 쉬운일은 아니다.

이 문제를 해결하기 위하여 결핵귄리 사업에 있어 민간단체가 선도적 교육적기능을 수행하는 겻은 1 차적인 역할이라 할 수 있다.

둘째는 정부사업을 지원하고 평가하는 역 활이다.

정부 결핵사업이 마련하고 있는 모든「서어비스」는 군민을 위한 것이고, 국민에 의해 적정히 이용 될 수 있도록 민간단체는 중간 역활을 해야 한다.

세째로 민간단체는 국민을 대표하는 한 단체로써 정부 결핵사업을 주시하고 그 성과를 평가하여 정부 결핵사업이 적정히 시행되도록 기술적으로 도우며, 모든 국민이 바라는 혜택을 받을 수 있도록 하여 야 한다.

그러나 결핵사업에 있어 민간단체의 역활은 시대와 나라마다의 환경에 따라 그 성과가 다르고 또 결핵관리의 발전단계에 따라 어느 한 가지 역활이 더욱 중요시되기도 한다.

대한결핵협회는 1953년도에 창설을 본 이래, 정부 결핵사업에 있어 선도자로서, 지원자로서, 그리 고 교육자로서의 역활을 하여 왔고 해마다 총재원의 약 $45 \%$ 를 정부사업을 기술적으로 뒷받침하는데 써 왔다.

한국에서는 1965 년과 1970 년도에 두 차레의 결핵실태조사를 했는테 결핵 이환률이 약 $20 \%$ 가량 감소된 것으로 보면 결핵사업의 성과가 나타나기 시작한 것이라고 생각되며 오는 1675년에 단 실태 조사를 할 계획인데 이 결과 역시도 더욱 개선된 것일 거라는 기대가 충분히 된다.

I. What is a voluntary agency?

A voluntary agency is an organization working beside the governmental system. It is an initiator, supporter and a reviewer of the governmental services to the people. The governmental body is formal as well as cumbersome in its procedures, but the voluntary agency should be freer and faster.
Human beinge are community oriented animals and there isn't a single place where a governing system of someform, whether large or small. is not existing.

The governing system and ideology may be changed according to the people's knowledge, desire and philosophy.

As we all know there has been and always will be voluntary movements or organizations working besides formal governmental systems, otherwise the 
government would not function properly or continue to improve its services.

\section{Table 1. Annual Christmas Seal Sales}

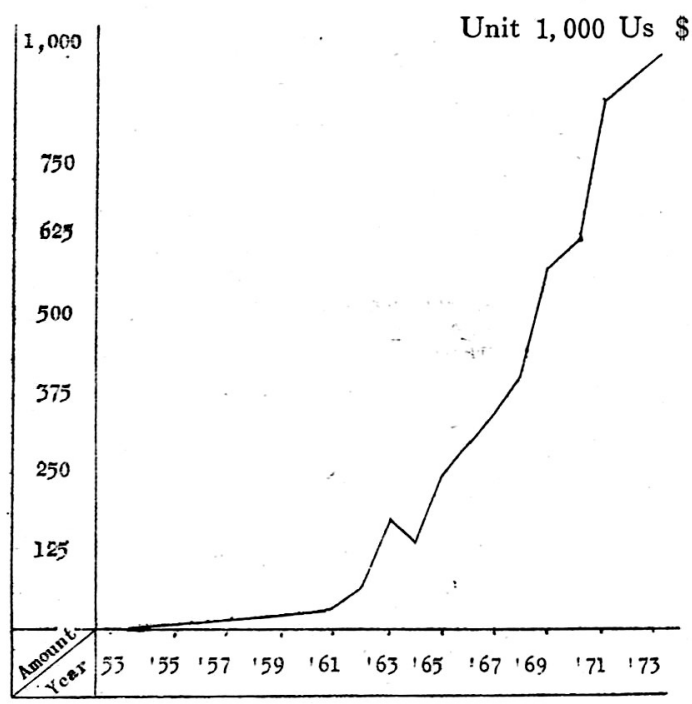

This Table shows the rapis pragresd of chrismas seal sales the KNTA's major fund raising campaigns, But as I said a moment's ago from next year this elevator will be downed and the speeial seasonal TB npam post stamp sales will be in it's place.

II. The roles of a voluntary agency in tuberculosis control

Tuberculosis is a common disease in many countries yet. The control of tuberculosis is well recognized as a governmental responsibility everywhere. However, to make this point clear to the governmental body, andhave them provide an adequate budgetfor this work is a very hard job for the voluntary agency at begining but it is a necessary task. Tuberculosis controlwork is a very serious matter but this fact is not easily recognized by the government and the people. The voluntary tuberculosis control agency of a nationmust assume the primary role as an educator, initiator and forerunner in theanti-tuberculosis program.

Next, the voluntary agency is a supporter of the governmtal anti-tuberculosis program. The overall responsibility of tuberculosis control belongs to the government, butafter all the useres of the services are the people. If they don't properly utilize the program, all the efforts, all the services given by the government would not do them any good at all.

At thispoint the voluntary workers must get in to supplement governmental services offered to the people. For instance most public hgalth man may think the treatment of tuberculosis is very simple but alss you know there arr so many defaulters. J think it will occures mou often when you do give the drugs uithout conaideration of anhuman relationship.

The voluntary agency can also provide an assistance by utilizing the skilled medical manpower they keep in their organization.

The voluntary agency in the control of tuberculosis is also a reviewer of the governmental program. The voluntary agencyis a representative of the people in a nation. The agency must watch and evaluate the governmental program to see if it is properly conducted and the people received the desired benefits. That is, the voluntary agency exists for the people. They must always work for the betterment of the people's health. Tnis is the foundation upon which the voluntary agency is built, and it can continue to exist only as long as it remains true to this ideal.

The roles of the voluntary agency in tuberculosis control will vary in its effectiveness according to. the circumstances. One role is more dominant than. others at a specific time or at a particular stage of development in the national tuberculosis control program.

Table 2, Budget for Tuberculosis Control by Service, 1974, by source

(Table 4.)

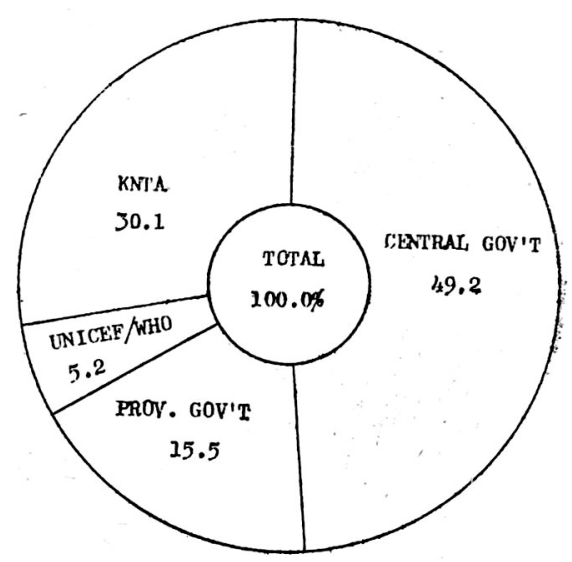


This Table shows, that in our country, upto present, the central govermeuts' budget for TB coutrol is very much inadequate

III. A brief hoistory of the Krean tuberculosis control program

Although there were several private organizations for a number of years and attempted Christmas seal sales campaigns, the official beginning of the Korean National Tuberculolsis Association(KNTA) was not unti 1953. From that same year on, the KNTA started to sell Christmas seals, and in 1954 the KNTA joined the IUAT. Mass X-ray surverys were initiated in 1956 by mobile units and in 1963 the central tuberculosis laboratory began its service.

The spntum examination as one of the cass finding methodos has been alsoe takn since 1968

The WHO/Tokyo tuberculosis control training conse has taken our country in there field trip courses for last severalyears and we very much aelighted to have mahy collegues from many wrmtries to enchange each other' views as wellas to make many friends.

In 1965 and 1970, the first and second national tuberculosis prevalence surveys were successfully carried out by the government, with the financial and technical assistance of WHO as well as that of the Korean National Tuberculosis Association.

The results of the tuberculosis jcontrol program between 1965 and 1970 were encouraging. A decrease of $20 \%$ in tuberculosis prevalence, from $5.1 \%$ to $4.2 \%$, was noted. The third survey is plannod to begin in 1975, and the result is also expected to show further improvement in the tuberculosis situation.

The Korean National Tuberculosis Association (KNTA) and not only been an initiator and educator, but also a strong partner with the government in tuberculosis control work. Also the KNTA has committed about $45 \%$ of its annual funds to finance the National program and also provided much needed technical assistance for thiswork.

By the way, beginning this year the Korean National Tuberculosis Association is expriencing a new way of fund raising. That is, the government
결핵 및 호흡기질환 Vol. 21, No 4. October 1974

decided to raise most of the Association's funds through the issue of a special seasonal post stamp sold at post offices, and the annual issue of Christmas seals will be much decreased in the amount.

The government's budget for tuberculosis control is not as much as we requested, but the change in fund raising raising methods this year could be thought of as a definite sign of further improvement in the government's understanding about the importance of the tuberculosis control problems.

If $\mathrm{J}$ say thesituation of our_KNTA at the present, weare in the stage of thitiatron and supplementation according to Dr. Thompson's Classification.

The voluntary agency and its staffs are hard workers. They must overcome many obstacls, but they never lose hope in the future.

Table 3. Budget for Tuberculosis Control by Service, 1974 National Government and KNTA only, by service

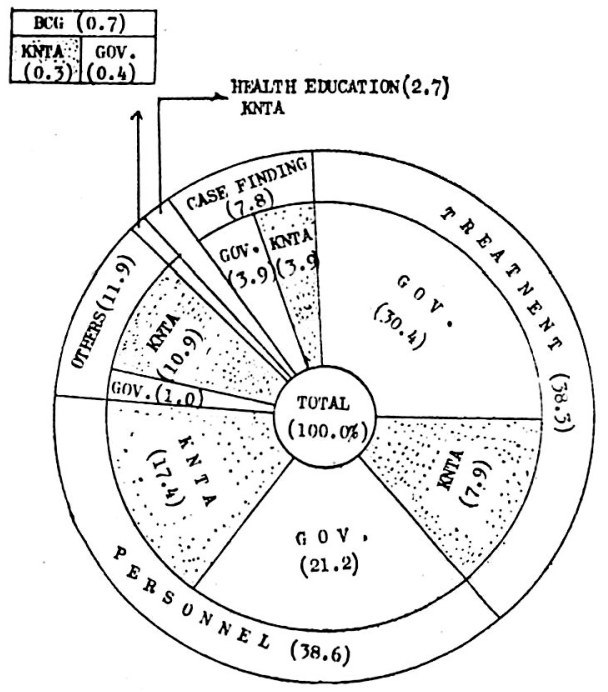

This Table shows that how much the KNTA, har been involved in various fields of National tuberculous control program,

That is why, in our country, the KNTA is and a big partner of the gavernment in the trberculosis control business.

Thank you. 